\title{
Hypercapnia Impairs ENaC Cell Surface Stability by Promoting Phosphorylation, Polyubiquitination and Endocytosis of $\beta$-ENaC in a Human Alveolar Epithelial Cell Line
}

OPEN ACCESS

Edited by:

Rudolf Lucas,

Augusta University, USA

Reviewed by:

Aaron Hanukoglu,

Tel Aviv University, Israel

Juerg Hamacher,

Lindenhof Hospital, Switzerland

${ }^{*}$ Correspondence:

István Vadász

istvan.vadasz@innere.med. uni-giessen.de

Specialty section: This article was submitted to Inflammation,

a section of the journal

Frontiers in Immunology

Received: 26 February 2017 Accepted: 04 May 2017

Published: 23 May 2017

Citation:

Gwoździńska P, Buchbinder BA, Mayer K, Herold S, Morty RE, Seeger W and Vadász I (2017) Hypercapnia Impairs ENaC Cell

Surface Stability by Promoting

Phosphorylation, Polyubiquitination and Endocytosis of $\beta$-ENaC in a Human Alveolar Epithelial Cell Line.

Front. Immunol. 8:591.

doi: 10.3389/fimmu.2017.00591

\begin{abstract}
Paulina Gwoździńska ${ }^{1}$, Benno A. Buchbinder ${ }^{1}$, Konstantin Mayer ${ }^{1}$, Susanne Herold ${ }^{1}$, Rory E. Morty ${ }^{1,2}$, Werner Seeger ${ }^{1,2}$ and István Vadász ${ }^{1 *}$
\end{abstract}

${ }^{1}$ Department of Internal Medicine, Justus Liebig University, Universities of Giessen and Marburg Lung Center, German Center for Lung Research, Giessen, Germany, ${ }^{2}$ Max Planck Institute for Heart and Lung Research, Bad Nauheim, Germany

Acute lung injury is associated with formation of pulmonary edema leading to impaired gas exchange. Patients with acute respiratory distress syndrome (ARDS) require mechanical ventilation to improve oxygenation; however, the use of relatively low tidal volumes (to minimize further injury of the lung) often leads to further accumulation of carbon dioxide (hypercapnia). Hypercapnia has been shown to impair alveolar fluid clearance (AFC), thereby causing retention of pulmonary edema, and may lead to worse outcomes; however, the underlying molecular mechanisms remain incompletely understood. AFC is critically dependent on the epithelial sodium channel (ENaC), which drives the vectorial transport of $\mathrm{Na}^{+}$across the alveolar epithelium. Thus, in the current study, we investigated the mechanisms by which hypercapnia effects ENaC cell surface stability in alveolar epithelial cells (AECs). Elevated $\mathrm{CO}_{2}$ levels led to polyubiquitination of $\beta$-ENaC and subsequent endocytosis of the $\alpha / \beta$-ENaC complex in AECs, which were prevented by silencing the E3 ubiquitin ligase, Nedd4-2. Hypercapnia-induced ubiquitination and cell surface retrieval of ENaC were critically dependent on phosphorylation of the Thr615 residue of $\beta$-ENaC, which was mediated by the extracellular signalregulated kinase (ERK)1/2. Furthermore, activation of ERK1/2 led to subsequent activation of AMP-activated protein kinase (AMPK) and c-Jun N-terminal kinase (JNK)1/2 that in turn phosphorylated Nedd4-2 at the Thr899 residue. Importantly, mutation of Thr899 to Ala markedly inhibited the $\mathrm{CO}_{2}$-induced polyubiquitination of $\beta$-ENaC and restored cell surface stability of the ENaC complex, highlighting the critical role of Nedd4-2 phosphorylation status in targeting ENaC. Collectively, our data suggest that elevated $\mathrm{CO}_{2}$ levels promote activation of the ERK/AMPK/JNK axis in a human AEC line, in which ERK1/2 phosphorylates $\beta$-ENaC whereas JNK mediates phosphorylation of Nedd4-2, thereby facilitating the channel-ligase interaction. The hypercapnia-induced ENaC dysfunction may contribute to impaired alveolar edema clearance and thus, interfering with these molecular mechanisms may improve alveolar fluid balance and lead to better outcomes in patients with ARDS.

Keywords: carbon dioxide, epithelial sodium channel, sodium transport, ubiquitination, alveolar fluid clearance, alveolar epithelium, mitogen-activated protein kinase signaling 


\section{INTRODUCTION}

Carbon dioxide $\left(\mathrm{CO}_{2}\right)$ is formed as a by-product of cellular respiration and is eliminated from the body during breathing (1). In respiratory disorders that are associated with alveolar hypoventilation, retention of $\mathrm{CO}_{2}$ is often detected, which leads to elevated $\mathrm{CO}_{2}$ concentrations in the blood, also known as hypercapnia (2). For example, patients with severe acute respiratory distress syndrome (ARDS) frequently present with hypercapnia, which may be enhanced due to mechanical ventilation with low tidal volumes to minimize further ventilatorinduced injuries to the lung (3). It is increasingly evident that the alveolar epithelium is capable of sensing of elevated $\mathrm{CO}_{2}$ levels, which initiate specific signaling signatures and alter the function of alveolar epithelial and other cells $(2,4)$. While some of these effects are anti-inflammatory, which may be beneficial in the context of excessive inflammation, others impair innate immunity, mitochondrial function, cellular repair, and alveolar epithelial barrier function, which are clearly detrimental in the setting of ARDS (5-10).

A fully functional alveolar epithelial barrier is crucial for maintaining optimal fluid balance and gas exchange in the lung $(11,12)$. In order to keep the alveolar space "dry," excess alveolar liquid is reabsorbed from the air space into the interstitium by a well-characterized active sodium transport process in which $\mathrm{Na}^{+}$enters the alveolar epithelial type I and type II cells through the apically located epithelial sodium channel $(\mathrm{ENaC})$ and is subsequently pumped out basolaterally by the Na,K-ATPase. This creates a $\mathrm{Na}^{+}$gradient, which drives paracellular movement of water leading to its clearance from the alveolar space (11, 12). Importantly, it has been clearly demonstrated that in most patients with ARDS alveolar fluid clearance (AFC) is impaired and that those patients with ARDS and impaired AFC the mortality is significantly higher than in ARDS patients with normal AFC (13).

Other than in the alveolar epithelium, ENaC molecules are expressed in the apical surface of various tight epithelia including kidney, colon, and respiratory airways where $\mathrm{ENaC}$ is located along the entire length of motile cilia and regulate osmolarity of the periciliary fluid (14). ENaC usually consists of three subunits ( $\alpha$ [or $\delta$, depending on the species, tissue, and cell type], $\beta$, and $\gamma$ ) $(15-17)$. A functional $\mathrm{ENaC}$ complex requires at least one $\alpha$ - or $\delta$-subunit, whereas the $\beta$ - and $\gamma$-subunits are necessary for proper trafficking and activity of the channel $(15,16,18)$. In line with this notion, mice lacking $\alpha$-ENaC are unable to clear lung fluid from the alveoli and die nearly immediately after birth (19). The significance of $\beta-\mathrm{ENaC}$ in the regulation of channel activity has been highlighted in transgenic mice overexpressing this subunit in the lung (20). In these animals, an increase in alveolar epithelial $\mathrm{Na}^{+}$uptake due to $\beta$-ENaC overexpression, probably by promoting trafficking of $\mathrm{ENaC}$ to the cell surface and enhancing channel activity, leads to lung dehydration and causes a CF-like phenotype. Cell surface abundance of $\mathrm{ENaC}$ is modified by the $\mathrm{E} 3$ ubiquitin ligase Nedd4-2, which by interaction with the PY motif, located at the C-termini of each subunit of the channel, promotes ubiquitination and subsequent clathrin-mediated endocytosis of the channel (21-23). Nedd4-2 $2^{-/-}$mice have enhanced $\mathrm{ENaC}$ expression and function; however, this genetic manipulation has lethal consequences (24). In contrast, overexpression of the ligase causes a decrease in $\mathrm{ENaC}$ density at the plasma membrane (PM) and reduces $\mathrm{Na}^{+}$transport (25).

Previous studies have proposed the involvement of phosphorylation in the mechanisms regulating Nedd4-2 binding to $\mathrm{ENaC}(26,27)$. For example, extracellular signal-regulated kinase (ERK), c-Jun N-terminal kinase (JNK), and recently also the cellular energy sensor, AMP-activated protein kinase (AMPK), have been described as potential modulators of the $\mathrm{ENaC} / \mathrm{Nedd} 4-2$ interaction by phosphorylating the E3 ligase or the target (28-32). We have previously described that hypercapnia markedly impairs AFC and initiates a specific signaling pattern in the alveolar epithelium, including rapid activation of ERK, AMPK, and JNK and subsequent downregulation of the $\mathrm{Na}$,K-ATPase $(7,8,33)$. Considering the pivotal role of $\mathrm{ENaC}$ in AFR and that several kinases, which have previously been suggested to alter $\mathrm{ENaC} /$ Nedd4-2 interaction, are activated by elevated $\mathrm{CO}_{2}$ levels, in the current study we sought to determine whether $\mathrm{ENaC}$ is effected by hypercapnia and provide evidence that excess $\mathrm{CO}_{2}$ initiates ERK-mediated $\beta$-ENaC phosphorylation and AMPK/JNKdependent activation of Nedd4-2 leading to an enhancement of $\beta$-ENaC polyubiquitination and, thus, to endocytosis of the $\mathrm{ENaC}$ complex form the cell surface. Since $\mathrm{ENaC}$ activity is essential for optimal lung fluid balance, the hypercapnia-induced alterations in $\mathrm{ENaC}$ cell surface stability may cause further aggravation of lung injury.

\section{MATERIALS AND METHODS}

\section{Cell Culture}

Human epithelial A549 cells (ATCC, CCL 185) were grown in DMEM supplemented with $10 \%$ fetal bovine serum and $100 \mathrm{U} / \mathrm{ml}$ penicillin, $100 \mu \mathrm{g} / \mathrm{ml}$ streptomycin as previously described (8). Experiments were performed on subconfluent monolayers of cells. Cells were incubated in a humidified atmosphere of 5\% $\mathrm{CO}_{2} / 95 \%$ air at $37^{\circ} \mathrm{C}$.

\section{$\mathrm{CO}_{2}$ Exposure}

A549 cells were treated with 40 or $120 \mathrm{mmHg} \mathrm{CO}_{2}$ (normocapnia and hypercapnia, respectively). Before each experiment, fresh solutions were prepared with DMEM-Ham's F-12 medium and Tris base. The buffering capacity of the experimental media was modified by changing the initial $\mathrm{pH}$ using Tris base to obtain a $\mathrm{pH}$ of 7.4 at 40 and $120 \mathrm{mmHgCO}_{2}$ (8). The desired $\mathrm{CO}_{2}$ concentrations and $\mathrm{pH}$ levels were obtained by equilibrating the experimental media overnight in a humidified chamber from BioSpherix Ltd. (NY, USA). The C-Chamber's atmosphere was controlled with a $\mathrm{PRO}-\mathrm{CO}_{2}$ Carbon Dioxide controller (Biospherix Ltd.). In the chamber, cells were treated with a $\mathrm{pCO}_{2}$ of 40 or $120 \mathrm{mmHg}$ while keeping $21 \% \mathrm{O}_{2}$ balanced with $\mathrm{N}_{2}$. Before and after $\mathrm{CO}_{2}$ exposure, $\mathrm{pH}, \mathrm{pCO}_{2}$, and $\mathrm{pO}_{2}$ levels in the media were measured using a Rapidlab blood gas analyzer (Siemens, Erlangen, Germany).

\section{Plasmids, Constructs, Site-Directed Mutagenesis, Antibodies, and Inhibitors}

pEYFP-C1-expressing $\alpha$-ENaC was constructed by PCR amplifying $\alpha-\mathrm{ENaC}$ gene using as a template pTNT- $\alpha-\mathrm{ENaC}$ and 
oligonucleotide primers $\alpha$-ENaC forward 5'-GAATTCAATGGAGGGGAACAAGCTGGAGG-3' and $\alpha$-ENaC reverse 5'-GGATCCCTTGTCATCGTCATCCTTGTAATCGGGCCCC CCCAGAGGAC-3'. The resulting amplicon was digested with EcoRI/BamH1 and ligated to the multiple cloning site (MCS) of pEYFP-C1 plasmid. The pEYFP-C1 vector contained the epitopetag eYFP at the N-terminus and a FLAG-tag at the C-terminus. Thus, anti-GFP or anti-FLAG antibodies recognize the $\alpha$-ENaC construct at a predicted size of $118 \mathrm{kDa}, 1,073$ amino acids $[\alpha-\mathrm{ENaC}$ $(90 \mathrm{kDa})$ plus YFP $(27 \mathrm{kDa})$ and FLAG $(1 \mathrm{kDa})]$. pcDNA3.1V5/His expressing $\beta$-ENaC was constructed by PCR amplifying $\beta$-ENaC gene using as a template cDNA transcribed from total mRNA isolated from A549 cells and oligonucleotide primers $\beta$ - $\mathrm{ENaC}$ forward 5'-CTCGGATCCACATGCACGTGAAGAAGTACCT-3' and $\beta$-ENaC reverse $5^{\prime}$-GCACTCGAGGATGGCATCACCCTCACTGT-3'. The resulting amplicon was digested with Xho1/ BamH1 and ligated to MCS of pcDNA3.1V5/His plasmid. Finally, E. coli $\mathrm{DH} 5 \alpha$ were transformed using the constructed plasmid. Anti-V5 antibodies recognize the $\beta$ - $\mathrm{ENaC}$ construct at a predicted size of $96 \mathrm{kDa}, 872$ amino acids [ $\beta$-ENaC plus $\mathrm{V} 5$ at the C-terminus $(1 \mathrm{kDa})]$. pCMV-HA-C-expressing $\gamma$-ENaC was constructed by PCR amplifying $\gamma$-ENaC gene using as a template pTNT- $\gamma \mathrm{ENaC}$ and oligonucleotide primers $\gamma$-ENaC forward 5'-AGGCCCGAATTCATGGCACCCGGAGAGAAGAT-3' and $\gamma$-ENaC reverse $5^{\prime}$-GTAGCCGGTACCGAGCTCATCCAGCATCTGGG-3'. The resulting amplicon was digested and ligated to MCS of pCMV-HA-C plasmid. The pCMV-HA-C vector contained the epitope-tag myc at the $\mathrm{N}$-terminus and an HA-tag at the C-terminus. Anti-HA antibodies recognize $\gamma$-ENaC at a predicted size of $97 \mathrm{kDa}, 881$ amino acids $[\gamma-\mathrm{ENaC}$ plus myc $(1 \mathrm{kDa})$ and $\mathrm{HA}(1 \mathrm{kDa})]$. pRK5-HA-ubiquitin was a gift from Ted Dawson [Addgene 17608 (34)] and the pCI HA NEDD4L plasmid was a gift from Joan Massague [Addgene 27000 (35)]. Site-directed mutagenesis was used to perform point mutation of T899A in human Nedd4-2 using Quick Change Mutagenesis Kit from Stratagene (La Jolla, CA, USA) in accordance to the manufacturer's instructions. The primer sequences were as follows: Nedd4-2 forward: 5'-ACTGCAGTTTGTCGCAGGGACATCGCGAG-3', Nedd4-2 reverse: $5^{\prime}$ CTCGCGATGTCCCTGCGACAAACTGCAGT-3'. Immunoblot analysis of epitope-tagged ENaC expressed in A549 cells were performed with a mouse anti-GFP antibody from Roche (Basel, Switzerland), a mouse anti-HA antibody (Covance, Princeton, NJ, USA), a mouse anti-V5 antibody and a mouse antibody against transferrin receptor used as loading control of biotinylated proteins from Invitrogen (Waltham, MA, USA; Figure S1 in Supplementary Material). A rabbit antibody directed against $\beta$-actin was used as loading control of cytoplasmic $\mathrm{ENaC}$ and was purchased from Sigma Aldrich (Saint Louis, MO, USA). The inhibitor of AMPK, Compound C, was from Merck Millipore (Darmstadt, Germany). The inhibitor of MEK, U0126 was from Promega (Fitchburg, WI, USA). siRNA against AMPK- $\alpha 1$ and Nedd4-2 and scrambled siRNA control were purchased from Santa Cruz Biotechnology (Dallas, TX, USA).

\section{Transient Transfection}

A549 cells were transiently transfected with eYFP- $\alpha-E N a C$, $\beta$-ENaC-V5, HA-ubiquitin, HA-Nedd4-2 wild type, or mutant by using nucleofection, as previously described (36). Briefly, cells were resuspended in $100 \mu \mathrm{l}$ of the nucleofection solution SF (Lonza, Cologne, Germany), and 4-6 $\mu$ g of DNA was added. Cells were placed in a cuvette and pulsed with the specified cell-type nucleofector program. After $10 \mathrm{~min}$ of incubation time, cells were cultured in DMEM supplemented with 10\% FBS, $100 \mathrm{U} / \mathrm{ml}$ penicillin, and $100 \mu \mathrm{g} / \mathrm{ml}$ streptomycin. In some studies, $24 \mathrm{~h}$ before nucleofection with $\mathrm{ENaC}$ plasmids, cells were transfected with siRNA using Lipofectamine RNAiMAX (Invitrogen, Waltham, MA, USA) according to the instructions of the manufacturer. Experiments were performed $48 \mathrm{~h}$ later.

\section{Cell Surface Biotinylation}

A549 cells were labeled for $20 \mathrm{~min}$ using $1 \mathrm{mg} / \mathrm{ml} \mathrm{EZ-Link}$ NHS-SS-biotin (Pierce Biotechnology, Waltham, MA, USA) and lysed in lysis buffer (50 mM HEPES, $150 \mathrm{mM} \mathrm{NaCl} 1 \mathrm{mM} \mathrm{EGTA}$, $10 \%$ glycerol, $1 \%$ TritonX100). Surface proteins were pulled down with streptavidin-agarose beads from Pierce Biotechnology (Waltham, MA, USA) and analyzed by SDS-PAGE and immunoblot, as described previously (8).

\section{Ubiquitination Studies}

A549 cells were transfected with $\mathrm{ENaC}$ plasmids $(2 \mu \mathrm{g}$ of each) and HA-ubiquitin $(3 \mu \mathrm{g})$. In some studies, cells were cotransfected with a plasmid coding HA-Nedd4-2 (wild type or mutant T899A, $2 \mu \mathrm{g}$ ) or siRNAs (against AMPK- $\alpha 1$, Nedd4-2, or scrambled). Cells were exposed to $40 \mathrm{mmHg} \mathrm{CO} 2$ (Ctrl) or to $120 \mathrm{mmHg} \mathrm{CO}_{2}\left(\mathrm{CO}_{2}\right)$ for 15 or $30 \mathrm{~min}$ and lysed on ice in lysis buffer (50 mM HEPES, $150 \mathrm{mM} \mathrm{NaCl}, 1 \mathrm{mM}$ EGTA, 10\% glycerol, $1 \%$ TritonX100), containing a protease inhibitor cocktail from Roche. After lysing the samples, proteins were resolved in $8 \%$ polyacrylamide gel, transferred to nitrocellulose membrane (Optitran; Schleicher \& Schuell, Dassel, Germany) using a semidry apparatus from Bio-Rad (Hercules, Berkeley, CA, USA). Membranes were blocked in 5\% fat-free dried milk powder and immunoblotted with anti-GFP or anti-V5 to detect $\alpha$ - or $\beta$-ENaC, respectively. Films were overexposed to detect $\mathrm{ENaC}$ ubiquitin conjugates.

\section{Phosphorylation Experiments}

Phosphorylation studies of ERK1/2, AMPK- $\alpha 1$, and c-Jun were performed using antibodies from Cell Signaling (Danvers, MA, USA). The anti-phospho- $\beta$-ENaC (T615) antibody was from Abcam (Cambridge, UK). A549 cells were treated with normal or elevated $\mathrm{CO}_{2}$ concentrations ( 40 or $120 \mathrm{mmHg}$, respectively) for the desired times, and then were washed with PBS twice and were lysed on ice in lysis buffer (50 mM HEPES, $150 \mathrm{mM} \mathrm{NaCl}$, $1 \mathrm{mM}$ EGTA, 10\% glycerol, $1 \%$ TritonX100). Samples having the same amount of protein were resuspended in Laemmli sample buffer and boiled for $10 \mathrm{~min}$ at $98^{\circ} \mathrm{C}$ and immunoblotted with specific antibodies.

\section{Statistics}

Data are presented as mean \pm SEM and were analyzed using one-way analysis of variance (ANOVA) followed by a multiple comparison with the Dunnet test. $p$ values of less than 0.05 were considered significant. GraphPad prism 6 (GraphPad software, San Diego, CA, USA) was used for the analysis and presentation of data. 


\section{RESULTS}

\section{Acute Exposure to Elevated $\mathrm{CO}_{2}$ Levels Leads to ENaC Endocytosis by Promoting Polyubiquitination of $\beta$-ENaC}

To test whether high $\mathrm{CO}_{2}$ levels promote endocytosis of $\mathrm{ENaC}$, A549 cells were co-transfected with plasmids encoding the human $\alpha$-and $\beta$-subunit of ENaC and the PM abundance of these proteins was measured after exposure of cells to physiological
( $\mathrm{pCO}_{2} 40 \mathrm{mmHg}$; normocapnia) or elevated $\left(\mathrm{pCO}_{2} 120 \mathrm{mmHg}\right.$; hypercapnia) $\mathrm{CO}_{2}$ concentrations at a $\mathrm{pH}_{\mathrm{e}}$ of 7.4 for $30 \mathrm{~min}$. Exposure of cells to elevated $\mathrm{CO}_{2}$ levels decreased $\alpha$ - and $\beta$-ENaC cell surface abundance by approximately 60\% (Figure 1A), whereas the total protein level remained unaffected (Figure 1B). To determine whether elevated $\mathrm{CO}_{2}$ levels lead to ubiquitination of either ENaC subunit, A549 cells were co-transfected with $\alpha$ - or $\beta$-ENaC and ubiquitin containing HA-tag (HA-Ub) and exposed the cells to 40 or $120 \mathrm{mmHg} \mathrm{CO}$ for $15 \mathrm{~min}$. Whereas no ubiquitination of $\alpha-\mathrm{ENaC}$ in response to hypercapnia was
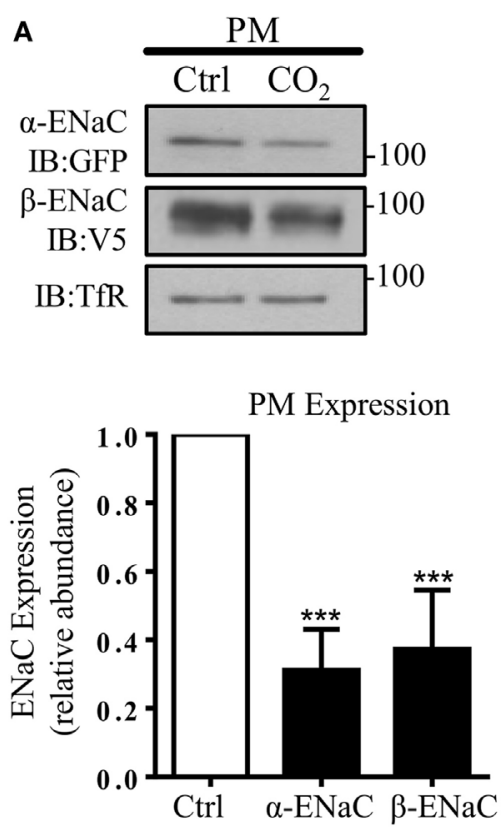

C $\alpha-\mathrm{ENaC}+\mathrm{HA}-\mathrm{Ub}$.

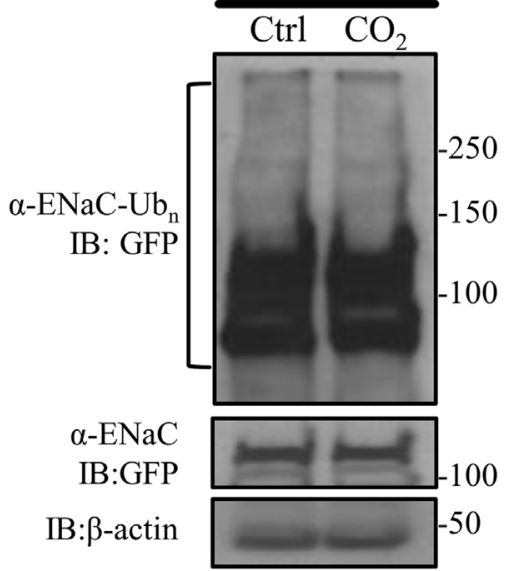

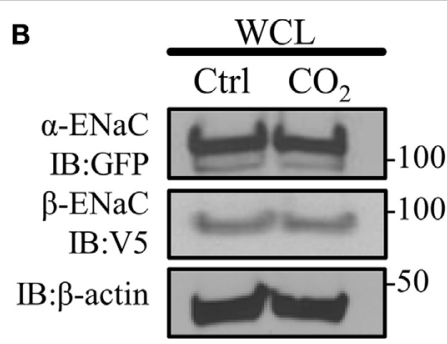

Intracellular Expression

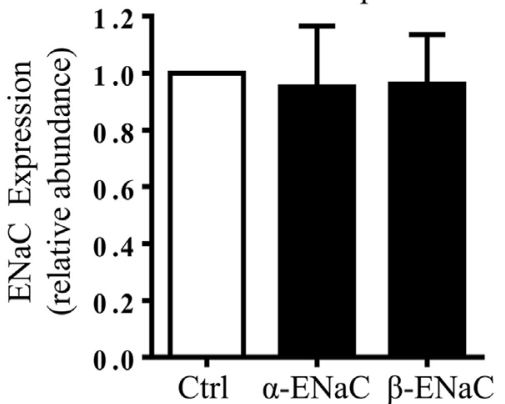

D

$\beta-\mathrm{ENaC}+\mathrm{HA}-\mathrm{Ub}$.

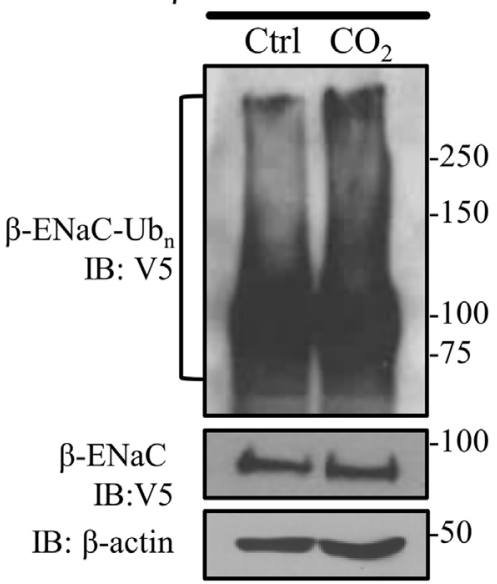

FIGURE 1 Acute exposure to elevated $\mathrm{CO}_{2}$ levels leads to epithelial sodium channel (ENaC) endocytosis by promoting polyubiquitination of $\beta$-ENaC (A) A549 cells were co-transfected with $\alpha$ - and $\beta$-ENaC and were exposed to $40 \mathrm{mmHg} \mathrm{CO}_{2}$ (Ctrl) or $120 \mathrm{mmHg} \mathrm{CO}_{2}\left(\mathrm{CO}_{2}\right)$ for 30 min at a pHe of 7.4 . Plasma membrane (PM) proteins were determined by streptavidin pull-downs and immunoblotting with anti-GFP to detect $\alpha-E N a C$ and anti-V5 to detect $\beta$-ENaC. Representative immunoblots of $\alpha-, \beta$-ENaC, and transferrin receptor (TfR) at the PM are shown. (B) A549 cells were co-transfected with $\alpha$ - and $\beta$-ENaC and were treated as described above. Protein abundance in whole cell lysate (WCL) was measured by immunoblotting. Representative immunoblots of $\alpha-, \beta$-ENaC, and $\beta$-actin are shown. Bars represent mean \pm SEM [n (number of independent experiments) $=3$; $\left.{ }^{* \star *} p<0.001\right]$. (C,D), A549 cells were co-transfected with ubiquitin containing HA-tag (HA-Ub) and $\alpha$-ENaC (C) or $\beta$-ENaC (D) and were exposed to 40 or $120 \mathrm{mmHg} \mathrm{CO}$ for 15 min. Total ubiquitinated $\alpha$-ENaC and $\beta$-ENaC was detected by immunoblots with anti-GFP or anti-V5 antibody. 
evident (Figure 1C), a marked increase in $\beta$-ENaC ubiquitination in total cell lysates was observed when cells were treated with elevated $\mathrm{CO}_{2}$ and immunoblotted with an antibody against V5 (Figure 1D). We detected a "polyubiquitin smear" above the molecular size of ENaC suggesting the presence of $\beta$-ENaC ubiquitin conjugates. This observation suggested that $\beta$-ENaC is a substrate of $\mathrm{CO}_{2}$-induced ubiquitination.

\section{Nedd4-2 Mediates the Hypercapnia-Induced ENaC Polyubiquitination and Endocytosis}

In subsequent studies, we silenced the endogenous Nedd4-2 with a specific siRNA to study whether Nedd4-2 mediates $\beta$-ENaC polyubiquitination during hypercapnia. Of note, the elevated $\mathrm{CO}_{2}$-induced $\mathrm{ENaC}$ ubiquitination was prevented by Nedd4-2 silencing (Figure 2A). To further test whether Nedd4-2 silencing altered ENaC PM stability, we measured cell surface ENaC abundance in A549 cells co-transfected with a scrambled siRNA (si-Scr.) or siRNA against Nedd4-2. Importantly, cells exposed to increased $\mathrm{CO}_{2}$ concentrations treated with siRNA targeting Nedd4- 2 had increased $\mathrm{ENaC} \alpha$ - and $\beta$-subunit density at the PM (Figure 2B). Thus, upon hypercapnia, Nedd4-2 targets $\beta$-ENaC, leading to polyubiquitination of the $\beta$-subunit of the channel, which results in decreased abundance of the $\alpha / \beta-\mathrm{ENaC}$ complex at the cell surface.

\section{Hypercapnia Induces ERK1/2-Dependent Phosphorylation of $\beta$-ENaC at Thr615 and Downregulates Surface Abundance of the Channel by Facilitating $\beta$-ENaC Polyubiquitination and Endocytosis of the $\alpha / \beta$-ENaC Complex}

In agreement with a previous report describing increased ERK $1 / 2$ activity in alveolar epithelial cells (AECs) exposed to hypercapnia (33), we found a rapid and transient phosphorylation of ERK1/2 in A549 cells exposed to elevated $\mathrm{CO}_{2}$ (Figure 3A). Moreover, ERK1/2 activation was paralleled by phosphorylation of $\beta$-ENaC at the Thr 615 residue (Figure 3B). To test whether ERK-dependent $\beta$-ENaC phosphorylation was sufficient to promote polyubiquitination of $\beta$-ENaC in response to high $\mathrm{CO}_{2}$, we co-transfected A549 cells with $\beta$-ENaC and HA-ubiquitin. Cells were pre-treated with the MEK (upstream of ERK) inhibitor $\mathrm{U} 0126$ and exposed to elevated $\mathrm{CO}_{2}$ concentrations for $30 \mathrm{~min}$. Inhibition of ERK prevented phosphorylation and polyubiquitination of the $\mathrm{ENaC} \beta$-subunit (Figure 3C). To further prove that the hypercapnia-induced $\mathrm{ENaC}$ cell surface retrieval is dependent on ERK1/2, A549 cells were co-transfected with ENaC plasmids, and exposed to normo- or hypercapnia as described above and observed that inhibition of ERK1/2 markedly increased the number of the ENaC molecules at the cell surface upon hypercapnia exposure (Figure 3D). Together, these data indicate that the hypercapnia-induced ERK1/2 activation promotes ENaC internalization by phosphorylation-dependent ubiquitination of the $\beta$-subunit of the channel.

\section{JNK1/2-Dependent Nedd4-2 Phosphorylation at Thr899 Facilitates $\beta$-ENaC Polyubiquitination and \\ Endocytosis}

Because JNK activation has been implicated in the $\mathrm{CO}_{2}$-induced signaling pattern in AEC, which led to inhibition of the $\mathrm{Na}$, K-ATPase (7), we next investigated the effects of JNK phosphorylation in AEC exposed to hypercapnia on ENaC. Activity of JNK1/2 was assessed by phosphorylation of c-Jun, a downstream target of JNK1/2. In line with the previously published data, we observed a rapid and time-dependent JNK activation induced by hypercapnia, which returned to baseline within $30 \mathrm{~min}$ of exposure to elevated $\mathrm{CO}_{2}$ levels (Figure 4A). To further investigate whether increased activity of Nedd4-2 is crucial to decrease hypercapnia-induced ENaC cell surface abundance, we next mutated a single amino acid in the catalytic domain of Nedd4-2 (T899A). The Thr899 residue within the HECT domain of the E3 ligase has previously been reported to be involved in the Nedd4-2-mediated ubiquitination of $\alpha$-ENaC (37). A549 cells were co-transfected with HA-Ub and HA-Nedd4-2 wild type (WT) or HA-Nedd4-2 mutant (T899) constructs and exposed to 40 or $120 \mathrm{mmHg} \mathrm{CO}$ for $30 \mathrm{~min}$. Of note, we found that phosphorylation of Thr899 played a central role in the hypercapniainduced ubiquitination of $\beta$-ENaC, as in A549 cells expressing the Nedd4-2 in which the Thr899 has been mutated to an alanine (T899A), which cannot be phosphorylated, the level of $\beta$-ENaC polyubiquitination significantly decreased (Figure 4B). To further investigate whether this decrease in the ubiquitination of $\beta$-ENaC due to the lack of phosphorylation at the Thr899 residue of Nedd4-2 correlated with an increase in ENaC cell surface stability, cell surface biotinylation studies were performed. Importantly, overexpression of the Nedd4-2 mutant (T899A) also prevented endocytosis of the $\alpha / \beta-\mathrm{ENaC}$ complex during hypercapnia (Figure 4C). Moreover and further confirming the central role of Nedd4-2 phosphorylation at Thr899 in the ubiquitination and subsequent endocytosis of ENaC, we observed increased levels of $\mathrm{ENaC}$ proteins at the cell surface after overexpression of the Nedd4-2 T899A mutant. Finally and in line with the above described findings, pretreatment of A549 cells with the potent and specific JNK inhibitor, SP600125, also fully prevented the hypercapnia-induced endocytosis of ENaC (Figure 4D).

\section{Hypercapnia Induces ENaC Endocytosis by ERK1/2-Dependent AMPK- $\alpha 1$ \\ Activation}

AMP-activated protein kinase, which has been shown to activate Nedd4-2 and inhibit ENaC (29), has also been described as one of the central mediators of the hypercapnia-induced alveolar epithelial dysfunction and a downstream target of ERK upon $\mathrm{CO}_{2}$ exposure $(8,33)$. Furthermore, we have previously observed that AMPK activates JNK1/2 in AEC when exposed to elevated $\mathrm{CO}_{2}$ levels (7). In line with these previously published observations, we measured a rapid and transient phosphorylation of AMPK- $\alpha 1$ in A549 cells exposed to hypercapnia (Figure 5A), which was dependent on activation of ERK (Figure 5B) and 

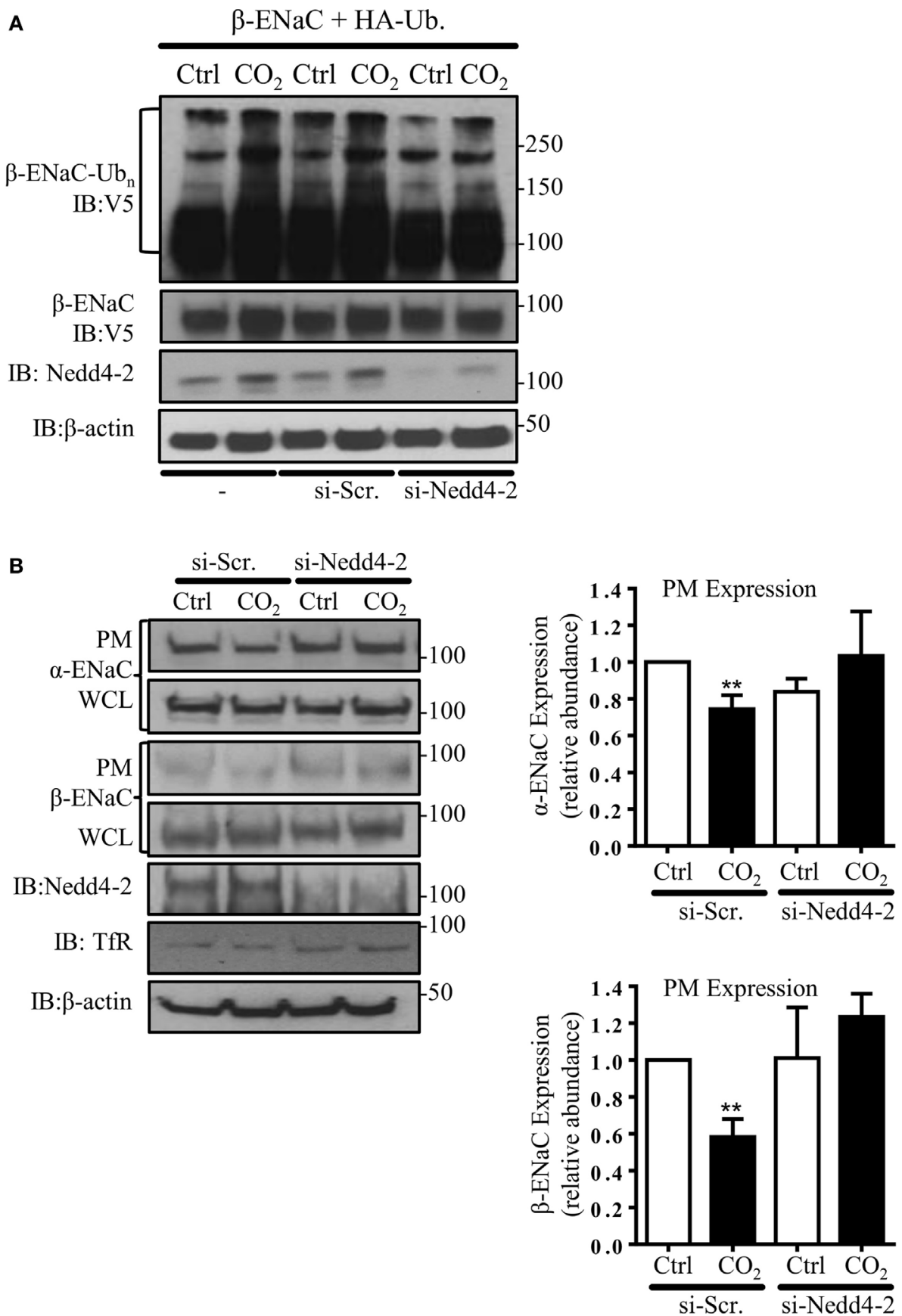

FIGURE 2 | Nedd4-2 mediates hypercapnia-induced epithelial sodium channel (ENaC) polyubiquitination and endocytosis. (A) A549 cells were co-transfected with $\beta$-ENaC, HA-ubiquitin, and siRNA against Nedd4-2 or a scrambled siRNA (si-Scr.) and were treated with 40 or 120 mmHg $\mathrm{CO}_{2}$ for 30 min and $\beta$-ENaC polyubiquitinated isoforms were determined. (B) A549 cells were co-transfected with $\alpha-, \beta$-ENaC, and siRNA targeting Nedd4-2 or scrambled siRNA. Biotinylated ENaC proteins were detected by immunoblotting. Representative immunoblots of $\alpha-, \beta$-ENaC, and transferrin receptor (TfR) at the plasma membrane $(\mathrm{PM})$ and total protein abundance [whole cell lysate $(\mathrm{WCL})]$ of ENaC proteins, $\beta$-actin, and Nedd4-2 are shown. Bars represent mean $\pm \mathrm{SEM}\left(n=3\right.$; $\left.{ }^{\star} p<0.01\right)$.

upstream of JNK (Figure S2 in Supplementary Material). To determine whether activation of AMPK was necessary for the hypercapnia-induced polyubiquitination of $\beta$-ENaC, A549 cells were co-transfected with $\beta$-ENaC, HA-ubiquitin, and a specific siRNA against AMPK- $\alpha 1$ (or a scrambled siRNA) and were exposed to normal or elevated $\mathrm{CO}_{2}$ levels and observed a significant decrease in polyubiquitination of $\beta$-ENaC after $\mathrm{CO}_{2}$ exposure (Figure 5C). As a second approach, endogenous AMPK was inhibited by compound $\mathrm{C}$ after co-transfection of A549 cells with $\beta$-ENaC and HA-ubiquitin. Similar to our data that we obtained with AMPK silencing, exposure of the cells to hypercapnia in the presence of the inhibitor markedly 

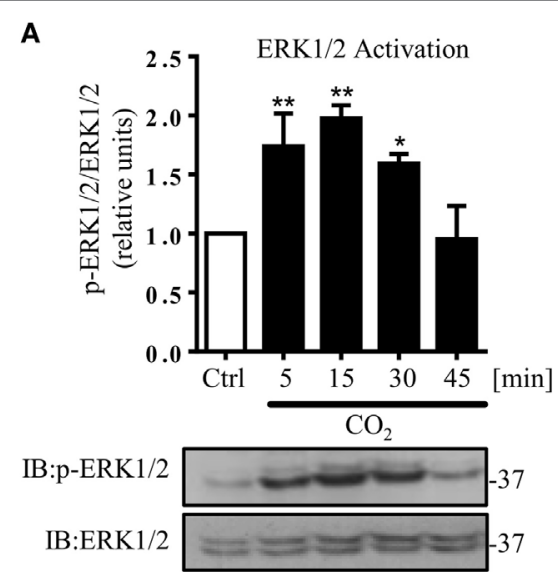

D

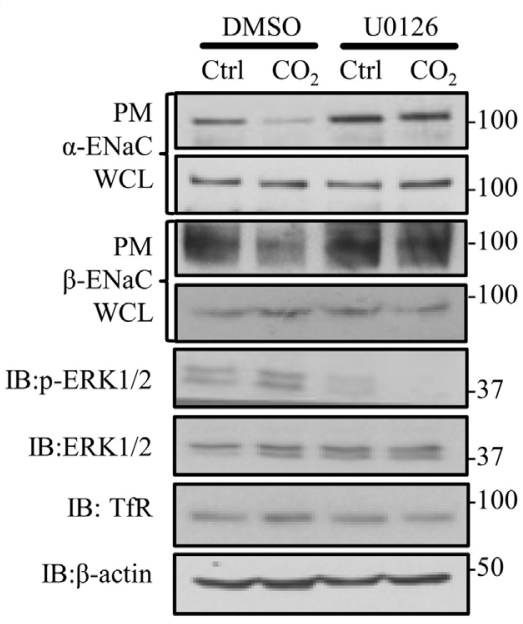

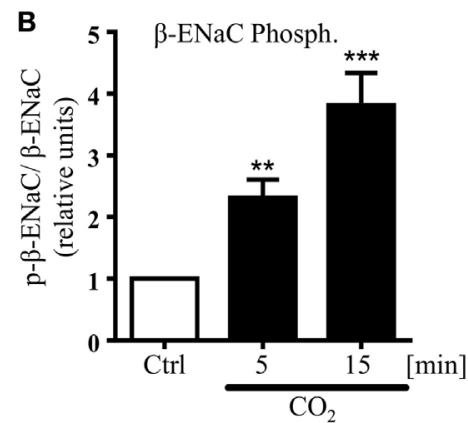
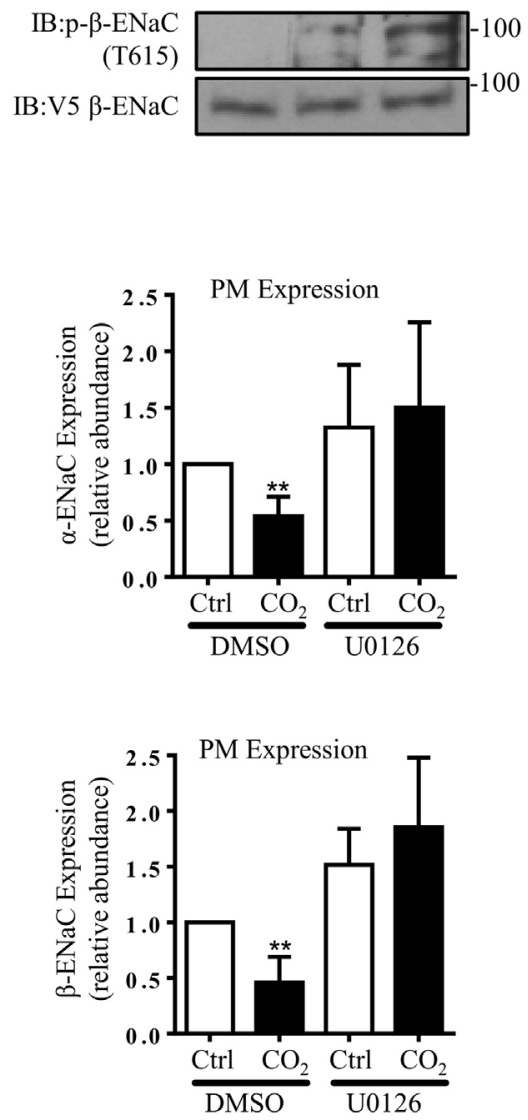

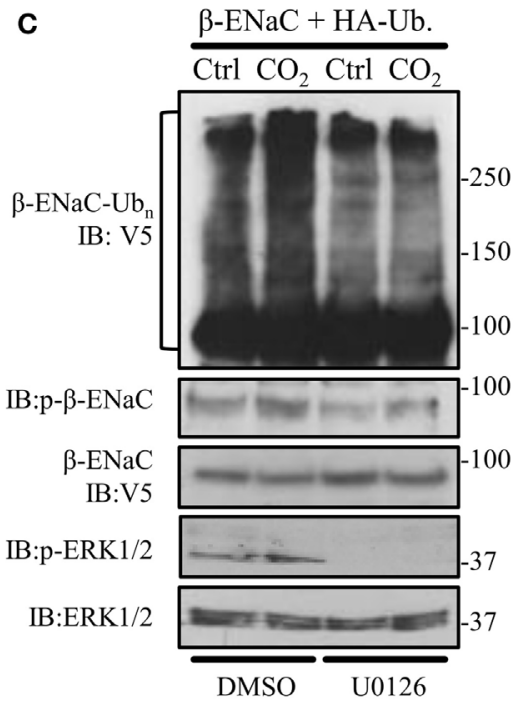

FIGURE 3 | Hypercapnia induces extracellular signal-regulated kinase (ERK)1/2-dependent phosphorylation of $\beta$-ENaC at T615 facilitating $\beta$-ENaC polyubiquitination and endocytosis of the $\boldsymbol{\alpha} / \boldsymbol{\beta}-\mathbf{E N a C}$ complex. (A) $\mathrm{A} 549$ cells were exposed to $40 \mathrm{mmHg} \mathrm{CO}\left(\mathrm{Ctrl}^{\prime}\right)$ for $15 \mathrm{~min}$ or to $120 \mathrm{mmHg} \mathrm{CO}_{2}\left(\mathrm{CO}_{2}\right)$ for 5-45 min at a $\mathrm{pH}_{e}$ of 7.4. Phosphorylation of ERK1/2 and the total amount of ERK1/2 were measured. The graph represents the $p$-ERK1/2/ERK1/2 ratio. Representative immunoblots of p-ERK1/2 and total ERK1/2 are shown. (B) A549 cells were co-transfected with $\beta$ - ENaC and were treated with $40 \mathrm{mmHg} \mathrm{CO}_{2}$ for $15 \mathrm{~min}$ or $120 \mathrm{mmHg} \mathrm{CO}$ for 5 and $15 \mathrm{~min}$ at a $\mathrm{pH}_{\mathrm{e}}$ of 7.4. Phosphorylation of $\beta$-ENaC at T615 (p- $\beta$-ENaC) and total $\beta$-ENaC were determined by immunoblotting. Graphs represent $p-\beta-E N a C / \beta-E N a C$ ratio. Representative immunoblots of $p-\beta-E N a C$ and $\beta-E N a C$ are shown. Values are expressed as mean $\pm \operatorname{SEM}\left(n=3\right.$; $\left.{ }^{\star} p<0.05 ;{ }^{*} p<0.01\right)$. (C) A549 cells were transfected with $\beta$-ENaC, HA-ubiquitin, and were exposed to $40 \mathrm{mmHg} \mathrm{CO}_{2}$ or $120 \mathrm{mmHg} \mathrm{CO}_{2}$ for $30 \mathrm{~min}$ at a $\mathrm{pH} \mathrm{H}_{\Theta}$ of 7.4 in the presence or absence of $\mathrm{U} 0126(10 \mu \mathrm{M}, 30$ min pretreatment). Total ubiquitinated $\beta$-ENaC was detected by immunoblotting with anti-V5 antibody. (D) A549 cells were co-transfected with $\alpha$ - and $\beta$-ENaC and were exposed to $\mathrm{CO}_{2}$ as described above. ENaC subunits at the plasma membrane (PM) were determined by biotin-streptavidin pull-downs and immunoblotting. Representative immunoblots of $\alpha$ - and $\beta$-ENaC at the PM, total protein abundance of epithelial sodium channel (ENaC) and p-ERK $1 / 2$ are shown. Bars represent mean \pm SEM $\left(n=3 ;{ }^{*} p<0.05 ;{ }^{* * *} p<0.001\right)$.

decreased the hypercapnia-induced $\beta$-ENaC polyubiquitination (Figure 5D). To further confirm the role of AMPK- $\alpha 1$ in the $\mathrm{CO}_{2}$-induced downregulation of $\mathrm{ENaC}$, we transfected A549 cells with $\alpha$ - and $\beta$-ENaC and exposed to elevated $\mathrm{CO}_{2}$ levels for $30 \mathrm{~min}$ in the presence or absence of the above mentioned siRNA against AMPK- $\alpha 1$ (Figure 5E) or compound C (Figure S3 in
Supplementary Material) and observed that silencing or inhibition of AMPK stabilized ENaC proteins at the PM upon hypercapnia. Taken together, these latter studies suggest that AMPK by activation of JNK and subsequent phosphorylation of Nedd4-2 plays a central role in the hypercapnia-induced ubiquitination and endocytosis of $\mathrm{ENaC}$. 


\section{DISCUSSION}

In the present study, we show that elevated $\mathrm{CO}_{2}$ levels initiate a specific signaling pattern leading to ubiquitination-mediated retrieval of $\mathrm{ENaC}$ from the $\mathrm{PM}$, thereby reducing cell surface abundance of the channel in a human AEC line. Hypercapnia is associated with a number of acute and chronic pulmonary diseases; however, it is not evident to what extent and by which mechanisms these elevated levels of $\mathrm{CO}_{2}$ may further impact on disease states. While hypercapnia and the associated acidosis have been shown to have anti-inflammatory effects, which might be advantageous at sites of excessive inflammation, recently, it has been clearly demonstrated that by impairing innate immunity, cellular repair, and alveolar epithelial function, elevated $\mathrm{CO}_{2}$ may play a role in the pathogenesis of $\operatorname{ARDS}$ and $\operatorname{COPD}(2,5$, 9, 10, 38). Furthermore, it is increasingly evident that patients with ARDS and COPD who present with hypercapnia have worse outcomes $(3,39,40)$.

A major function of the alveolar epithelium is the clearance of excess alveolar fluid, thereby promoting effective gas exchange. This clearance is mediated by the concerted action of various sodium transporters, among which the apically located ENaC
A

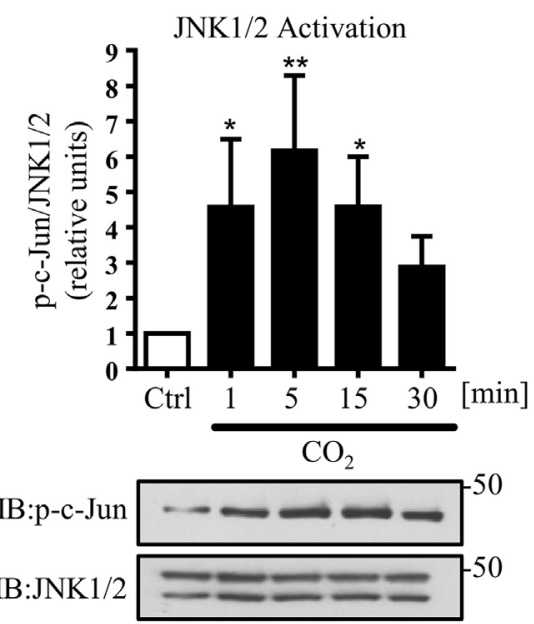

C

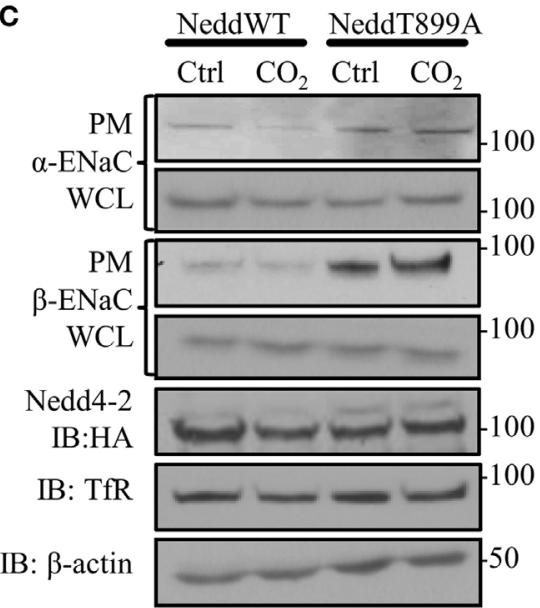

B
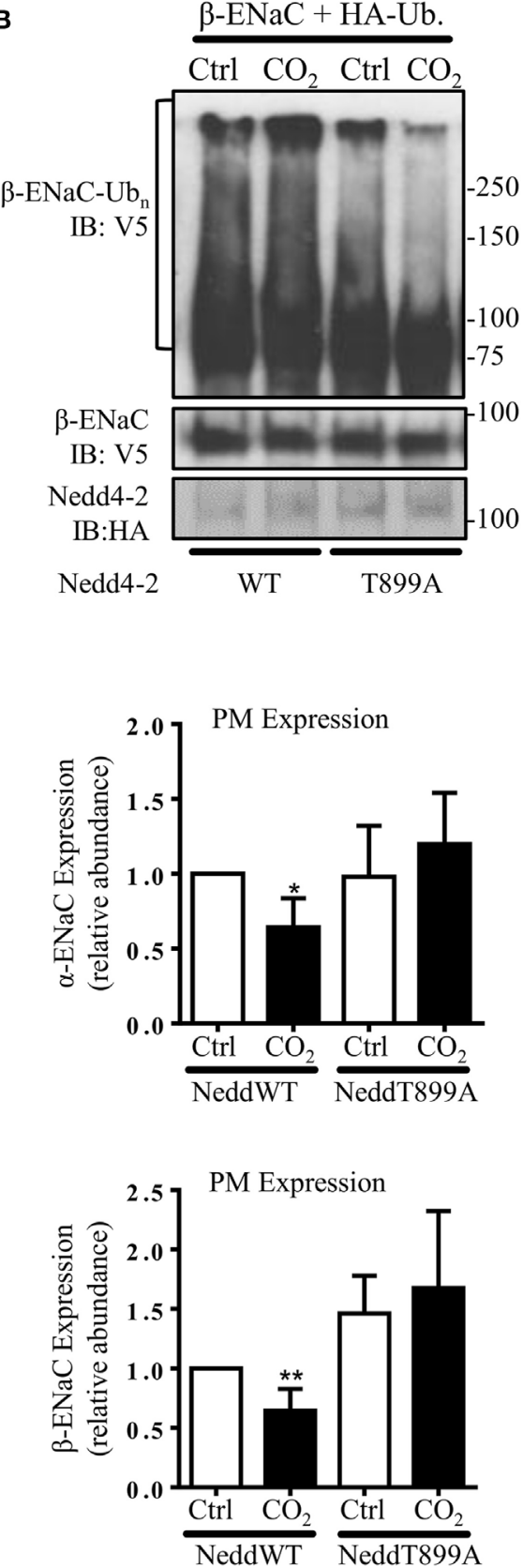

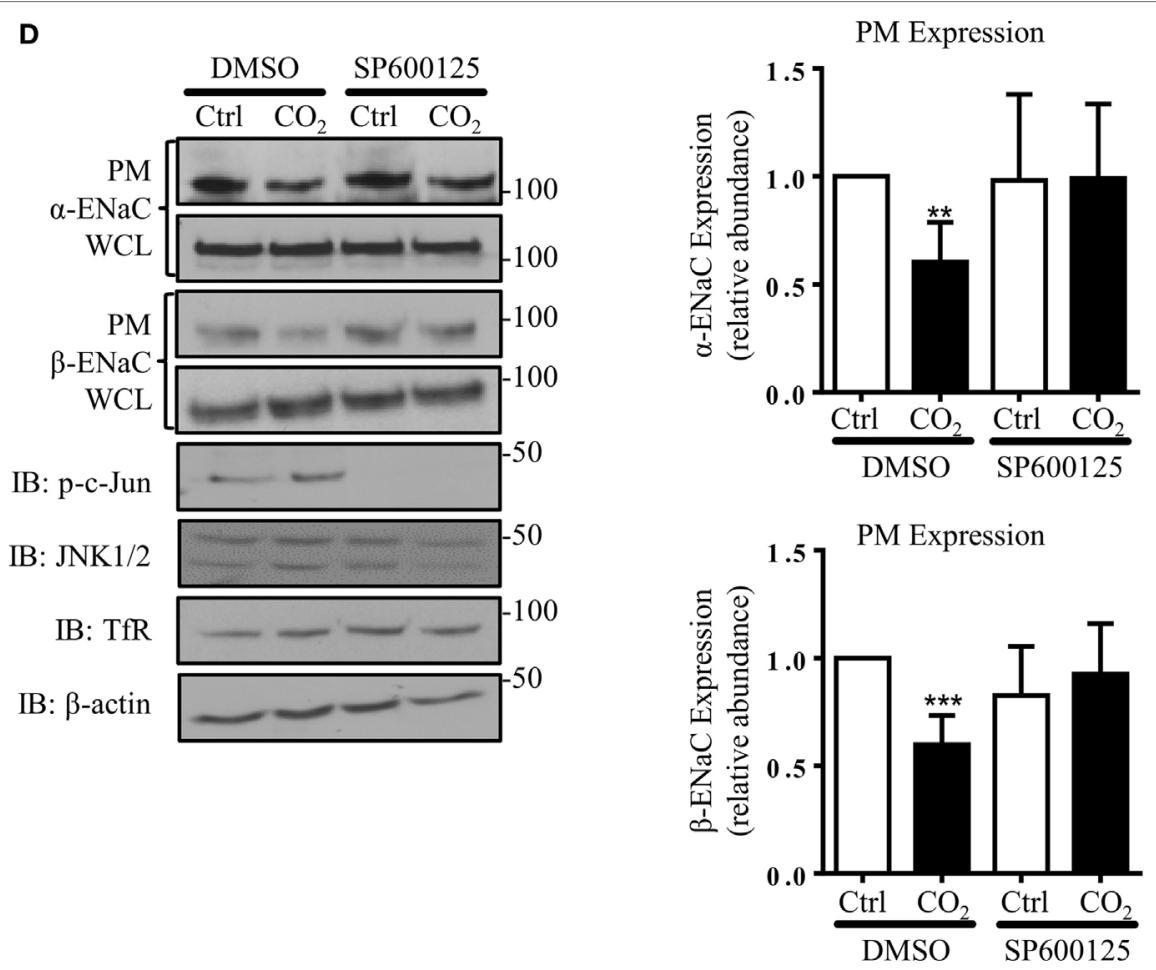

FIGURE 4 | C-Jun N-terminal kinase (JNK)1/2-dependent Nedd4-2 phosphorylation at Thr899 facilitates $\beta$-ENaC polyubiquitination and endocytosis. (A) A549 cells were exposed to $40 \mathrm{mmHg} \mathrm{CO}$ (Ctrl) for $15 \mathrm{~min}$ or to $120 \mathrm{mmHg} \mathrm{CO}_{2}\left(\mathrm{CO}_{2}\right)$ for 1 to $30 \mathrm{~min}$ at a pHe of 7.4 and the phosphorylation of C-Jun and the total amount of JNK1/2 were measured by immunoblotting. Graph represents the p-c-Jun/JNK1/2 ratio. Representative immunoblots of p-c-Jun and total JNK1/2 levels are shown. Values are expressed as mean \pm SEM $\left(n=3 ;{ }^{*} p<0.05 ;{ }^{* *} p<0.01\right)$. (B) A549 cells were co-transfected with $\beta$-ENaC, HA-ubiquitin, and HA-Nedd4-2 wild type (WT) or mutant (T899A). Cells were treated with $40 \mathrm{mmHg} \mathrm{CO}_{2}$ or $120 \mathrm{mmHg} \mathrm{CO}_{2}$ for $30 \mathrm{~min}$ at a pHe of 7.4. Total ubiquitinated $\beta$-ENaC was detected by immunoblotting with anti-V5 antibody. (C) A549 cells were co-transfected with $\alpha$ - and $\beta$-ENaC and Nedd4-2 wild type or mutant and were exposed to $\mathrm{CO}_{2}$ as described above. Epithelial sodium channel (ENaC) at the plasma membrane (PM) was determined by biotin-streptavidin pull-downs and immunoblotting. Representative immunoblots of $\alpha$ - and $\beta$-ENaC at the PM, total protein abundance of ENaC, Nedd4-2, and $\beta$-actin are shown. Mean \pm SEM $\left(n=3\right.$; $\left.{ }^{*} p<0.05\right)$. (D) A549 cells were co-transfected with $\alpha$ - and $\beta$ - $\mathrm{ENaC}$ exposed to $40 \mathrm{mmHg} \mathrm{CO}_{2}$ or $120 \mathrm{mmHg} \mathrm{CO}_{2}$ for $30 \mathrm{~min}$ at a pHe of 7.4 in the presence or absence of SP600125 (25 MM, 30 min pretreatment). ENaC at the PM was determined by biotin-streptavidin pull-downs and immunoblotting. Representative immunoblots of $\alpha$ - and $\beta$-ENaC at the PM, total protein abundance of ENaC, $p$-c-Jun, JNK1/2, and $\beta$-actin are shown. Bars represent mean \pm SEM $\left(n=5 ;{ }^{* \star} p<0.01 ;{ }^{* \star} p<0.001\right)$.

and the basolateral $\mathrm{Na}, \mathrm{K}$-ATPase have been identified as key players. Indeed, we have previously shown that the Na,K-ATPase is downregulated by hypercapnia; however, a potential regulation of $\mathrm{ENaC}$ by carbon dioxide has not been previously investigated. Various factors have been shown to affect ENaC cell surface abundance and function, including interleukin-1 $\beta$, interleukin-4, transforming growth factor- $\beta$, LPS, or hypoxia (41-45), which similar to hypercapnia are often observed in patients with respiratory failure. As reducing hypercapnia without further damaging the lung is challenging, a better understanding of the molecular patterns initiated by elevated $\mathrm{CO}_{2}$ levels may help us to interfere with the deleterious signals, thereby rescuing or at least not further aggravating lung damage.

Ubiquitination is a posttranslational modification that regulates trafficking and stability of proteins (46). Numerous studies described that depending on the stimulus ENaC subunits may undergo multimono- or polyubiquitination leading to channel retrieval from the cell surface or degradation of ENaC (47-49). It is also well documented that the phosphorylation status of target molecules and the E3 ubiquitin ligase often play a pivotal role in the initiation of ubiquitination $(50,51)$. Previous findings established the significance of mitogen-activated protein kinase (MAPK) in the hypercapnia-induced impairment of AFC $(7,33)$. Moreover, it has also been described that ERK and JNK, two prominent members of the MAPK family, may alter the phosphorylation status of $\mathrm{ENaC}$ and the $\mathrm{E} 3$ ligase of the channel, Nedd4-2, respectively $(31,37)$.

Thus, we first investigated whether elevated $\mathrm{CO}_{2}$ concentrations affect $\mathrm{ENaC}$ cell surface stability by a mechanism involving ubiquitination of the channel and whether the MAPK pathway is involved in the hypercapnia-induced signaling events. Of note, a remarkable and rapid increase in polyubiquitination of $\beta$-ENaC and a significant reduction of the cell surface abundance of the $\alpha / \beta$-ENAC complex were observed in AEC exposed to hypercapnia, as early as $30 \mathrm{~min}$ after $\mathrm{CO}_{2}$ exposure, suggesting that $\mathrm{ENaC}$ function is probably sensitive to changes in $\mathrm{CO}_{2}$ levels. In contrast, in the first half an hour after $\mathrm{CO}_{2}$ exposure, total intracellular levels of $\mathrm{ENaC}$ remained unchanged, suggesting that $\mathrm{CO}_{2}$ influenced 


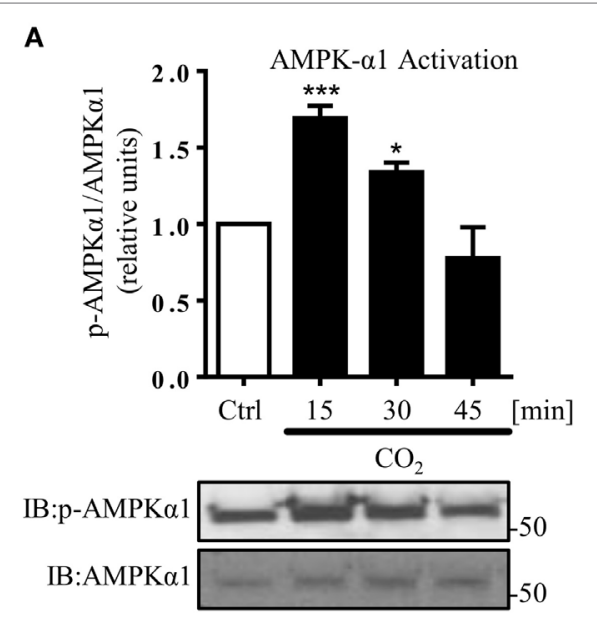

D

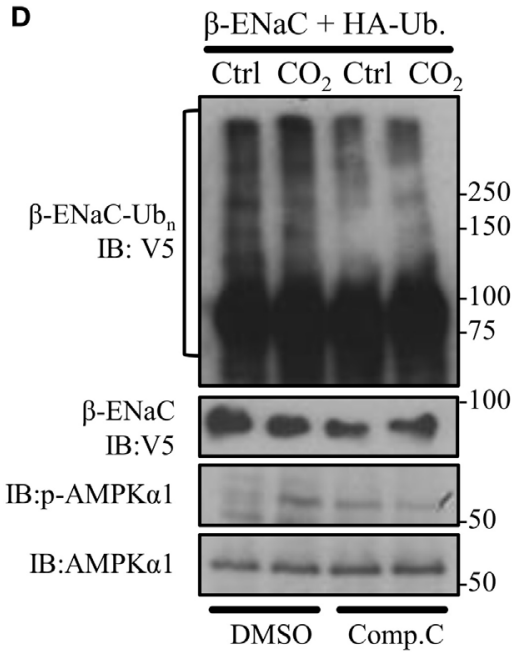

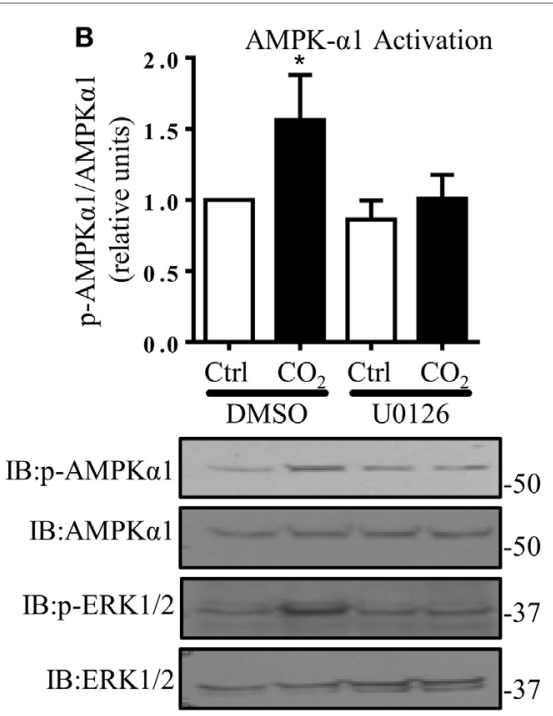

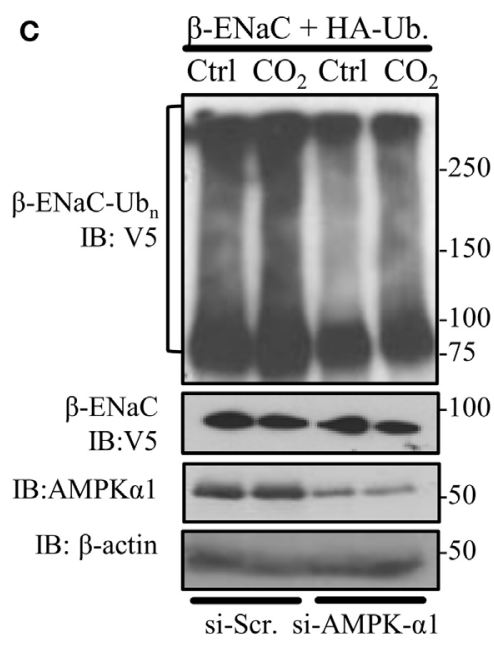

E

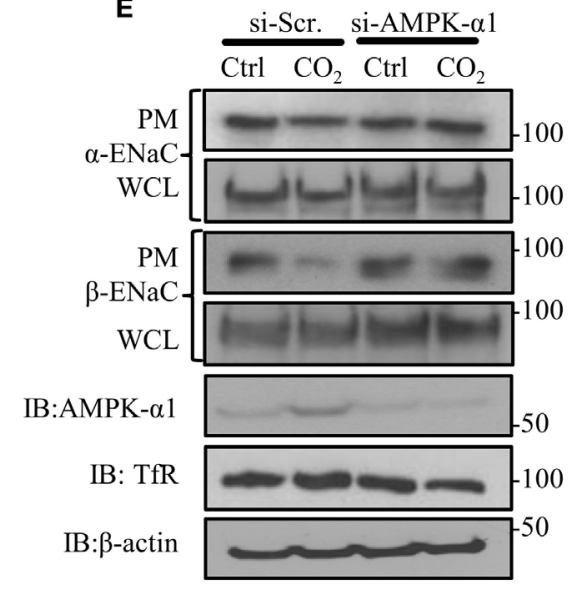

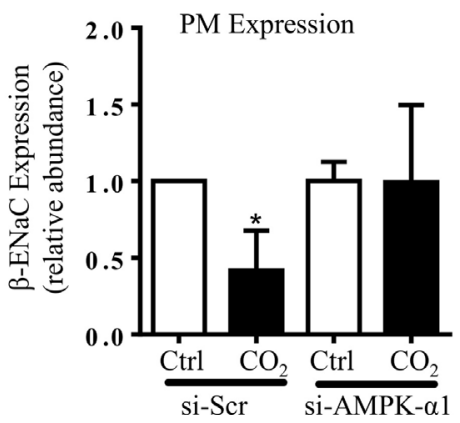

FIGURE 5 | Hypercapnia induces epithelial sodium channel (ENaC) endocytosis via extracellular signal-regulated kinase (ERK)1/2-dependent AMPK- $\alpha 1$ activation. (A) A549 cells were exposed to $40 \mathrm{mmHg} \mathrm{CO}$ (Ctrl) for $15 \mathrm{~min}$ or to $120 \mathrm{mmHg} \mathrm{CO}\left(\mathrm{CO}_{2}\right)$ for $15-45 \mathrm{~min}$ at a pHe of 7.4. The phosphorylation of AMPK- $\alpha 1$ at Thr172 and the total amount of AMPK- $\alpha 1$ were measured by immunoblotting. Graph represents the $\mathrm{p}-\mathrm{AMPK}-\alpha 1 / \mathrm{AMPK}-\alpha 1$ ratio. Representative immunoblots of p-AMPK- $\alpha 1$ and total AMPK- $\alpha 1$ are shown. (B) A549 cells were treated with $40 \mathrm{mmHg} \mathrm{CO}\left(\mathrm{Ctrl}^{\prime}\right)$ or with $120 \mathrm{mmHg} \mathrm{CO}_{2}\left(\mathrm{CO}_{2}\right)$ for $15 \mathrm{~min}$ at a pH $\mathrm{pH}_{\mathrm{e}} \mathrm{7.4}$ in the presence or absence of $10 \mu \mathrm{M} \cup 0126$ (30 min pretreatment). Phosphorylation of AMPK- $\alpha 1$ at Thr172, $\mathrm{p}$-ERK1/2, and the total amount of both proteins were determined by immunoblotting. Graph represents the p-AMPK- $\alpha 1 /$ AMPK- $\alpha 1$ ratio. Representative immunoblots of $p-A M P K-\alpha 1$, p-ERK $1 / 2$ and total level of AMPK- $\alpha 1$ and ERK1/2 are shown. Values are expressed as mean \pm SEM $\left(n=3 ;{ }^{*} p<0.05 ;{ }^{* \star *} p<0.001\right)$. (C) A549 cells were co-transfected with $\beta$-ENaC, HA-ubiquitin, and siRNA targeting AMPK- $\alpha 1$ or a scrambled siRNA and were treated with 40 or $120 \mathrm{mmHg} \mathrm{CO}_{2}$ for $30 \mathrm{~min}$. $\beta$-ENaC polyubiquitinated isoforms were determined with anti-V5 antibody. Representative immunoblots of $\beta$-ENaC, AMPK- $\alpha 1$, and $\beta$-actin are shown. (D) A549 cells were co-transfected with $\beta$-ENaC and HA-ubiquitin and were treated with $40 \mathrm{mmHg} \mathrm{CO}_{2}$ or $120 \mathrm{mmHg} \mathrm{CO}_{2}$ for 30 min at a pHe of 7.4 in the presence or absence of compound C (20 $\mu \mathrm{M}, 30$ min pretreatment). Total ubiquitinated $\beta$-ENaC was detected as described above. Representative immunoblots of $\beta$-ENaC, p-AMPK- $\alpha 1$, and total AMPK- $\alpha 1$ are shown. (E) Cells were co-transfected with $\alpha$ - and $\beta$-ENaC and siRNA targeting AMPK- $\alpha 1$ or a scrambled siRNA and exposed to 40 mmHg $\mathrm{CO}_{2}$ or $120 \mathrm{mmHg} \mathrm{CO}$ for 30 min at a pHe of 7.4. Biotinylated $\mathrm{ENaC}$ proteins were detected by immunoblotting. Representative western blots of $\alpha$ and $\beta-\mathrm{ENaC}$ at the plasma membrane (PM) and total protein abundance of ENaC, $\mathrm{p}-\mathrm{AMPK}-\alpha 1$, and AMPK- $\alpha 1$ are shown. Bars present mean $\pm \mathrm{SEM}$ $\left(n=3 ;{ }^{*} p<0.05 ;{ }^{* *} p<0.01\right)$. 
the trafficking of the channel rather than protein degradation. Furthermore, no significant changes in the ubiquitination status of $\alpha$-ENaC have been detected upon hypercapnic treatment, highlighting and further confirming the central regulatory role of $\beta$-ENaC in the trafficking of the channel (52).

Our data demonstrate that elevated $\mathrm{CO}_{2}$ levels cause a rapid and time-dependent ERK1/2 activation followed by phosphorylation of $\beta$-ENaC at the Thr615 residue. Moreover, genetic inhibition of Nedd4-2, the E3 ubiquitin ligase that drives ubiquitination of the various $\mathrm{ENaC}$ subunits (49), by a specific siRNA reduced $\beta$-ENaC polyubiquitination and prevented the hypercapnia-induced redistribution of $\alpha$ - and $\beta$-ENaC from the PM to the intracellular store, indicating a central role for Nedd4-2 in ENaC ubiquitination and endocytosis in AEC exposed to hypercapnia. Indeed, ERK1/2 has previously been described as a negative regulator of $\mathrm{ENaC}$. For example, Eaton et al. showed that protein kinase $\mathrm{C}-\delta$ drives ERK activation leading to ENaC internalization (30). Another study established that the ERK-mediated $\mathrm{ENaC}$ downregulation is promoted by phosphorylation $\beta$ - and $\gamma$-ENaC, resulting in enhancement of Nedd4-2/ENaC interaction and thus, decreased $\mathrm{Na}^{+}$transport (31). Therefore, hypercapnia by enhancing ERK activity promotes phosphorylation of the $\mathrm{ENaC} \beta$-subunit, which may increase the affinity of the E3 ubiquitin ligase to ENaC.

We have previously shown that JNK is also implicated in $\mathrm{CO}_{2}$ responses and that phosphorylation of the kinase is required for the $\mathrm{CO}_{2}$-induced inhibition of the $\mathrm{Na}, \mathrm{K}$-ATPase in the alveolar epithelium (7). The significance of JNK in cellular adaptation to stress has been shown by several studies (53). Of note, the possible role of JNK in modulating Nedd4-2 activity and ENaC current has been reported in polarized kidney epithelial cells (28). Remarkably, this study also showed that the Thr899 residue in the HECT (homologous to the E6-AP carboxyl terminus) domain of Nedd4-2 may be phosphorylated by JNK1, which was required for ubiquitination of $\alpha$-ENaC (28). To assess the potential involvement of JNK-mediated Nedd4-2 phosphorylation in the hypercapnia-induced downregulation of $\mathrm{ENaC}$, we mutated Thr899 to Ala to prevent phosphorylation of the E3 ligase at this residue. Importantly, this point mutation largely prevented the $\mathrm{CO}_{2}$-induced polyubiquitination of $\beta$-ENaC although activation of JNK was evident and stabilized $\alpha$ - and $\beta$-ENaC at the cell surface. Thus, our data together with the previously published literature suggest that phosphorylation of Nedd4-2 by JNK at the Thr899 residue is critical for the hypercapnia-induced ubiquitination of $\beta-\mathrm{ENaC}$, which drives endocytosis of the $\mathrm{ENaC}$ complex from the PM in AEC.

We have previously shown that AMPK, a cellular metabolic sensor that inhibits several ion transporters including the cystic fibrosis transmembrane conductance regulator, Na,K-ATPase, and $\mathrm{ENaC}$, is rapidly activated by hypercapnia $(8,29,54)$. Regarding the regulation of $\mathrm{ENaC}$, it has been shown that chemical stimulation of AMPK by 5-aminoimidazole-4-carboxamide-1-beta-4-ribofuranoside inhibited $\mathrm{ENaC}$ activity in lung epithelial cells (55). Moreover, enhanced abundance of ENaC channels at the cell surface was reported in the distal airways in AMPK- $\alpha 1^{-/-}$mice (28). Interestingly, AMPK has also been reported to regulate Nedd4-2 activity $(26,29)$. In the current study, treatment of AEC with a specific siRNA against AMPK- $\alpha 1$ or an AMPK- $\alpha$ inhibitor, compound $\mathrm{C}$ markedly decreased $\mathrm{CO}_{2}$-induced $\beta$-ENaC polyubiquitination and endocytosis of $\alpha$-, and $\beta-\mathrm{ENaC}$, which is consistent with previous findings showing that in human embryonic kidney cells, AMPK activation promoted Nedd4-2/ENaC association (26). Furthermore, and in line with a previously published study (7), we also show that in the context of hypercapnia, AMPK is an upstream regulator of JNK. Thus, it is probable that the AMPK-regulated effects of $\mathrm{CO}_{2}$ on Nedd4-2 and ENaC are indirect and mediated by JNK. Moreover, although AMPK is an early element of the $\mathrm{CO}_{2}$-induced signaling pattern, its activation appears to be downstream of ERK upon hypercapnic exposure. This is of particular importance as ERK appears two have a dual role in the hypercapnia-induced downregulation of $\mathrm{ENaC}$. On the one hand, it rapidly phosphorylates the $\beta$-subunit of the channel and by activating AMPK and JNK, it indirectly promotes phosphorylation of the E3 ligase Nedd4-2 as well. Of note, both of these phosphorylation events seem to be critically required for the $\mathrm{CO}_{2}$-induced ubiquitination and subsequent endocytosis of $\mathrm{ENaC}$, probably by enhancing the association of the E3 ligase and the target molecule.

Our study has some clear limitations. Although we show a rapid activation of ERK and a subsequent phosphorylation of $\beta$-ENaC at the Thr615 residue, which is a known target of ERK, we have not investigated the potential rescue of $\beta$-ENaC ubiquitination or trafficking of the ENaC complex after preventing phosphorylation at this specific site. A mutation of this residue will be necessary to definitely prove that ERK-promoted phosphorylation of $\beta$-ENaC at this residue drives the downregulation of the channel upon hypercapnia. Moreover, the current study was performed exclusively in AECs and further in vivo investigations will be necessary to establish the role of the hypercapnia-induced signaling events identified in the current manuscript in ENaC-driven AFC and alveolar epithelial barrier dysfunction in an animal model of hypercapnic acute lung injury.

Taken together, our study shows for the first time that upon exposure to elevated $\mathrm{CO}_{2}$ levels, $\mathrm{ENaC}$ cell surface abundance is rapidly downregulated in a human AEC line by a specific, $\mathrm{CO}_{2}$-induced and ERK-, AMPK-, and JNK-mediated signaling pathway, which promotes phosphorylation of both $\beta$-ENaC and Nedd4-2, leading to ubiquitination of $\beta$-ENaC and subsequent internalization of the $\alpha / \beta-\mathrm{ENaC}$ complex. This novel signaling pathway may contribute to the persistence of alveolar edema and thus, interfering with these molecular mechanisms may improve alveolar fluid balance and lead to better outcomes in patients with ARDS and hypercapnia.

\section{AUTHOR CONTRIBUTIONS}

Conception or design of the work: PG and IV; acquisition, analysis, or interpretation of data: PG, BB, KM, SH, RM, WS, and IV; drafting the work: $\mathrm{PG}$ and IV; revising it critically for important intellectual content: PG, BB, KM, SH, RM, WS, and IV. All the authors approved the final version of the manuscript and agreed to be accountable for all aspects of the work in ensuring that questions related to the accuracy or integrity of any part of the work are appropriately investigated and resolved. 


\section{ACKNOWLEDGMENTS}

The authors thank Mrs. Miriam Wessendorf (Universities of Giessen and Marburg Lung Center) for her excellent technical assistance.

\section{FUNDING}

This work was supported by grants from the Excellence Cluster "Cardio Pulmonary System" (ECCPS), the German Center for Lung Research (DZL), the Landes-Offensive zur Entwicklung Wissenschaftlich-ökonomischer Exzellenz (LOEWE) of the

\section{REFERENCES}

1. Putnam RW, Filosa JA, Ritucci NA. Cellular mechanisms involved in $\mathrm{CO}(2)$ and acid signaling in chemosensitive neurons. Am J Physiol Cell Physiol (2004) 287(6):C1493-526. doi:10.1152/ajpcell.00282.2004

2. Vadasz I, Hubmayr RD, Nin N, Sporn PH, Sznajder JI. Hypercapnia: a nonpermissive environment for the lung. Am J Respir Cell Mol Biol (2012) 46(4):417-21. doi:10.1165/rcmb.2011-0395PS

3. Nin N, Muriel A, Penuelas O, Brochard L, Lorente JA, Ferguson ND, et al. Severe hypercapnia and outcome of mechanically ventilated patients with moderate or severe acute respiratory distress syndrome. Intensive Care Med (2017) 43(2):200-8. doi:10.1007/s00134-016-4611-1

4. Cummins EP, Selfridge AC, Sporn PH, Sznajder JI, Taylor CT. Carbon dioxidesensing in organisms and its implications for human disease. Cell Mol Life Sci (2014) 71(5):831-45. doi:10.1007/s00018-013-1470-6

5. Briva A, Vadasz I, Lecuona E, Welch LC, Chen J, Dada LA, et al. High CO2 levels impair alveolar epithelial function independently of $\mathrm{pH}$. PLoS One (2007) 2(11):e1238. doi:10.1371/journal.pone.0001238

6. Gates KL, Howell HA, Nair A, Vohwinkel CU, Welch LC, Beitel GJ, et al. Hypercapnia impairs lung neutrophil function and increases mortality in murine pseudomonas pneumonia. Am J Respir Cell Mol Biol (2013) 49 (5):821-8. doi:10.1165/rcmb.2012-0487OC

7. Vadasz I, Dada LA, Briva A, Helenius IT, Sharabi K, Welch LC, et al. Evolutionary conserved role of c-Jun-N-terminal kinase in $\mathrm{CO}_{2}$-induced epithelial dysfunction. PLoS One (2012) 7(10):e46696. doi:10.1371/journal. pone. 0046696

8. Vadasz I, Dada LA, Briva A, Trejo HE, Welch LC, Chen J, et al. AMP-activated protein kinase regulates $\mathrm{CO}_{2}$-induced alveolar epithelial dysfunction in rats and human cells by promoting $\mathrm{Na}, \mathrm{K}-\mathrm{ATPase}$ endocytosis. J Clin Invest (2008) 118(2):752-62. doi:10.1172/JCI29723

9. Vohwinkel CU, Lecuona E, Sun H, Sommer N, Vadasz I, Chandel NS, et al. Elevated $\mathrm{CO}(2)$ levels cause mitochondrial dysfunction and impair cell proliferation. J Biol Chem (2011) 286(43):37067-76. doi:10.1074/jbc.M111.290056

10. Laffey JG, Honan D, Hopkins N, Hyvelin JM, Boylan JF, McLoughlin P. Hypercapnic acidosis attenuates endotoxin-induced acute lung injury. Am J Respir Crit Care Med (2004) 169(1):46-56. doi:10.1164/rccm.200205-394OC

11. Matthay MA, Folkesson HG, Clerici C. Lung epithelial fluid transport and the resolution of pulmonary edema. Physiol Rev (2002) 82(3):569-600. doi:10.1152/physrev.00003.2002

12. Mutlu GM, Sznajder JI. Mechanisms of pulmonary edema clearance. Am J Physiol Lung Cell Mol Physiol (2005) 289(5):L685-95. doi:10.1152/ajplung. 00247.2005

13. Ware LB, Matthay MA. Alveolar fluid clearance is impaired in the majority of patients with acute lung injury and the acute respiratory distress syndrome. Am J Respir Crit Care Med (2001) 163(6):1376-83. doi:10.1164/ ajrccm.163.6.2004035

14. Enuka Y, Hanukoglu I, Edelheit O, Vaknine H, Hanukoglu A. Epithelial sodium channels $(\mathrm{ENaC})$ are uniformly distributed on motile cilia in the oviduct and the respiratory airways. Histochem Cell Biol (2012) 137(3):339-53. doi:10.1007/s00418-011-0904-1

15. Bhalla $\mathrm{V}$, Hallows $\mathrm{KR}$. Mechanisms of $\mathrm{ENaC}$ regulation and clinical implications. J Am Soc Nephrol (2008) 19(10):1845-54. doi:10.1681/ASN.2008020225
Hessen State Ministry of Higher Education, Research and the Arts, and the Deutsche Forschungsgemeinschaft (Clinical Research Unit KFO309/1) (for KM, SH, RM, WS, and IV). IV was supported by a Clinical Scientist Career Program grant from the ECCPS.

\section{SUPPLEMENTARY MATERIAL}

The Supplementary Material for this article can be found online at http://journal.frontiersin.org/article/10.3389/fimmu.2017.00591/ full\#supplementary-material.

16. Matalon S, Bartoszewski R, Collawn JF. Role of epithelial sodium channels in the regulation of lung fluid homeostasis. Am J Physiol Lung Cell Mol Physiol (2015) 309(11):L1229-38. doi:10.1152/ajplung.00319.2015

17. Hanukoglu I, Hanukoglu A. Epithelial sodium channel (ENaC) family: phylogeny, structure-function, tissue distribution, and associated inherited diseases. Gene (2016) 579(2):95-132. doi:10.1016/j.gene.2015.12.061

18. Canessa CM, Schild L, Buell G, Thorens B, Gautschi I, Horisberger JD, et al. Amiloride-sensitive epithelial Na+ channel is made of three homologous subunits. Nature (1994) 367(6462):463-7. doi:10.1038/367463a0

19. Hummler E, Barker P, Gatzy J, Beermann F, Verdumo C, Schmidt A, et al. Early death due to defective neonatal lung liquid clearance in alpha-ENaC-deficient mice. Nat Genet (1996) 12(3):325-8. doi:10.1038/ng0396-325

20. Mall M, Grubb BR, Harkema JR, O’Neal WK, Boucher RC. Increased airway epithelial $\mathrm{Na}+$ absorption produces cystic fibrosis-like lung disease in mice. Nat Med (2004) 10(5):487-93. doi:10.1038/nm1028

21. Abriel H, Loffing J, Rebhun JF, Pratt JH, Schild L, Horisberger JD, et al. Defective regulation of the epithelial Na+ channel by Nedd4 in Liddle's syndrome. J Clin Invest (1999) 103(5):667-73. doi:10.1172/JCI5713

22. Snyder PM, Olson DR, McDonald FJ, Bucher DB. Multiple WW domains, but not the $\mathrm{C} 2$ domain, are required for inhibition of the epithelial $\mathrm{Na}+$ channel by human Nedd4. J Biol Chem (2001) 276(30):28321-6. doi:10.1074/jbc. M011487200

23. Rotin D, Staub O. Role of the ubiquitin system in regulating ion transport. Pflugers Arch (2011) 461(1):1-21. doi:10.1007/s00424-010-0893-2

24. Boase NA, Rychkov GY, Townley SL, Dinudom A, Candi E, Voss AK, et al. Respiratory distress and perinatal lethality in Nedd4-2-deficient mice. Nat Commun (2011) 2:287. doi:10.1038/ncomms1284

25. Knight KK, Olson DR, Zhou R, Snyder PM. Liddle's syndrome mutations increase $\mathrm{Na}+$ transport through dual effects on epithelial $\mathrm{Na}+$ channel surface expression and proteolytic cleavage. Proc Natl Acad Sci U S A (2006) 103(8):2805-8. doi:10.1073/pnas.0511184103

26. Carattino MD, Edinger RS, Grieser HJ, Wise R, Neumann D, Schlattner U, et al. Epithelial sodium channel inhibition by AMP-activated protein kinase in oocytes and polarized renal epithelial cells. J Biol Chem (2005) 280(18): 17608-16. doi:10.1074/jbc.M501770200

27. Debonneville C, Flores SY, Kamynina E, Plant PJ, Tauxe C, Thomas MA, et al. Phosphorylation of Nedd4-2 by Sgk1 regulates epithelial $\mathrm{Na}(+)$ channel cell surface expression. EMBO J (2001) 20(24):7052-9. doi:10.1093/ emboj/20.24.7052

28. Almaca J, Kongsuphol P, Hieke B, Ousingsawat J, Viollet B, Schreiber R, et al AMPK controls epithelial $\mathrm{Na}(+)$ channels through Nedd4-2 and causes an epithelial phenotype when mutated. Pflugers Arch (2009) 458(4):713-21. doi:10.1007/s00424-009-0660-4

29. Bhalla V, Oyster NM, Fitch AC, Wijngaarden MA, Neumann D, Schlattner U, et al. AMP-activated kinase inhibits the epithelial $\mathrm{Na}+$ channel through functional regulation of the ubiquitin ligase Nedd4-2. J Biol Chem (2006) 281(36):26159-69. doi:10.1074/jbc.M606045200

30. Eaton AF, Yue Q, Eaton DC, Bao HF. ENaC activity and expression is decreased in the lungs of protein kinase C-alpha knockout mice. Am J Physiol Lung Cell Mol Physiol (2014) 307(5):L374-85. doi:10.1152/ajplung.00040.2014

31. Shi H, Asher C, Chigaev A, Yung Y, Reuveny E, Seger R, et al. Interactions of beta and gamma ENaC with Nedd 4 can be facilitated by an ERK-mediated 
phosphorylation. J Biol Chem (2002) 277(16):13539-47. doi:10.1074/jbc. M111717200

32. Yang LM, Rinke R, Korbmacher C. Stimulation of the epithelial sodium channel $(\mathrm{ENaC})$ by cAMP involves putative ERK phosphorylation sites in the C termini of the channel's beta- and gamma-subunit. J Biol Chem (2006) 281(15):9859-68. doi:10.1074/jbc.M512046200

33. Welch LC, Lecuona E, Briva A, Trejo HE, Dada LA, Sznajder JI. Extracellular signal-regulated kinase (ERK) participates in the hypercapnia-induced $\mathrm{Na}$, K-ATPase downregulation. FEBS Lett (2010) 584(18):3985-9. doi:10.1016/j. febslet.2010.08.002

34. Lim KL, Chew KC, Tan JM, Wang C, Chung KK, Zhang Y, et al. Parkin mediates nonclassical, proteasomal-independent ubiquitination of synphilin-1: implications for Lewy body formation. J Neurosci (2005) 25(8):2002-9. doi:10.1523/ JNEUROSCI.4474-04.2005

35. Gao S, Alarcon C, Sapkota G, Rahman S, Chen PY, Goerner N, et al. Ubiquitin ligase Nedd4L targets activated Smad2/3 to limit TGF-beta signaling. Mol Cell (2009) 36(3):457-68. doi:10.1016/j.molcel.2009.09.043

36. Grzesik BA, Vohwinkel CU, Morty RE, Mayer K, Herold S, Seeger W, et al. Efficient gene delivery to primary alveolar epithelial cells by nucleofection. Am J Physiol Lung Cell Mol Physiol (2013) 305(11):L786-94. doi:10.1152/ ajplung.00191.2013

37. Hallows KR, Bhalla V, Oyster NM, Wijngaarden MA, Lee JK, Li H, et al. Phosphopeptide screen uncovers novel phosphorylation sites of Nedd4-2 that potentiate its inhibition of the epithelial $\mathrm{Na}+$ channel. J Biol Chem (2010) 285(28):21671-8. doi:10.1074/jbc.M109.084731

38. Doerr CH, Gajic O, Berrios JC, Caples S, Abdel M, Lymp JF, et al. Hypercapnic acidosis impairs plasma membrane wound resealing in ventilator-injured lungs. Am J Respir Crit Care Med (2005) 171(12):1371-7. doi:10.1164/rccm. 200309-1223OC

39. Kohnlein T, Windisch W, Kohler D, Drabik A, Geiseler J, Hartl S, et al. Noninvasive positive pressure ventilation for the treatment of severe stable chronic obstructive pulmonary disease: a prospective, multicentre, randomised, controlled clinical trial. Lancet Respir Med (2014) 2(9):698-705. doi:10.1016/ S2213-2600(14)70153-5

40. Bellani G, Laffey JG, Pham T, Fan E, Brochard L, Esteban A, et al. Epidemiology, patterns of care, and mortality for patients with acute respiratory distress syndrome in intensive care units in 50 countries. JAMA (2016) 315(8):788-800. doi:10.1001/jama.2016.0291

41. Galietta LJV, Pagesy P, Folli C, Caci E, Romio L, Costes B, et al. IL-4 is a potent modulator of ion transport in the human bronchial epithelium in vitro. J Immunol (2002) 168(2):839-45. doi:10.4049/jimmunol.168.2.839

42. Gille T, Randrianarison-Pellan N, Goolaerts A, Dard N, Uzunhan Y, Ferrary E, et al. Hypoxia-induced inhibition of epithelial $\mathrm{Na}(+)$ channels in the lung. Role of Nedd4-2 and the ubiquitin-proteasome pathway. Am J Respir Cell Mol Biol (2014) 50(3):526-37. doi:10.1165/rcmb.2012-0518OC

43. Migneault F, Boncoeur E, Morneau F, Pascariu M, Dagenais A, Berthiaume Y. Cycloheximide and lipopolysaccharide downregulate alphaENaC mRNA via different mechanisms in alveolar epithelial cells. Am J Physiol Lung Cell Mol Physiol (2013) 305(10):L747-55. doi:10.1152/ajplung.00023.2013

44. Roux J, Kawakatsu H, Gartland B, Pespeni M, Sheppard D, Matthay MA, et al. Interleukin-1beta decreases expression of the epithelial sodium channel alpha-subunit in alveolar epithelial cells via a p38 MAPK-dependent signaling pathway. J Biol Chem (2005) 280(19):18579-89. doi:10.1074/jbc. M410561200

45. Peters DM, Vadász I, Wujak L, Wygrecka M, Olschewski A, Becker C, et al. TGF-beta directs trafficking of the epithelial sodium channel $\mathrm{ENaC}$ which has implications for ion and fluid transport in acute lung injury. Proc Natl Acad Sci U S A (2014) 111(3):E374-83. doi:10.1073/pnas.1306798111

46. Hershko A, Ciechanover A. The ubiquitin system. Annu Rev Biochem (1998) 67:425-79. doi:10.1146/annurev.biochem.67.1.425

47. Butterworth MB, Edinger RS, Ovaa H, Burg D, Johnson JP, Frizzell RA. The deubiquitinating enzyme UCH-L3 regulates the apical membrane recycling of the epithelial sodium channel. J Biol Chem (2007) 282(52):37885-93. doi:10.1074/jbc.M707989200

48. Wiemuth D, Ke Y, Rohlfs M, McDonald FJ. Epithelial sodium channel (ENaC) is multi-ubiquitinated at the cell surface. Biochem J (2007) 405(1):147-55. doi:10.1042/BJ20060747

49. Zhou R, Patel SV, Snyder PM. Nedd4-2 catalyzes ubiquitination and degradation of cell surface ENaC. J Biol Chem (2007) 282(28):20207-12. doi:10.1074/ jbc.M611329200

50. Butterworth MB, Frizzell RA, Johnson JP, Peters KW, Edinger RS. PKAdependent $\mathrm{ENaC}$ trafficking requires the SNARE-binding protein complexin. Am JPhysiol Renal Physiol (2005) 289(5):F969-77. doi:10.1152/ajprenal. 00390.2003

51. Hunter T. The age of crosstalk: phosphorylation, ubiquitination, and beyond. Mol Cell (2007) 28(5):730-8. doi:10.1016/j.molcel.2007.11.019

52. Firsov D, Schild L, Gautschi I, Merillat AM, Schneeberger E, Rossier BC. Cell surface expression of the epithelial $\mathrm{Na}$ channel and a mutant causing Liddle syndrome: a quantitative approach. Proc Natl Acad Sci U S A (1996) 93(26):15370-5. doi:10.1073/pnas.93.26.15370

53. Weston CR, Davis RJ. The JNK signal transduction pathway. Curr Opin Cell Biol (2007) 19(2):142-9. doi:10.1016/j.ceb.2007.02.001

54. Hallows KR, Raghuram V, Kemp BE, Witters LA, Foskett JK. Inhibition of cystic fibrosis transmembrane conductance regulator by novel interaction with the metabolic sensor AMP-activated protein kinase. J Clin Invest (2000) 105(12):1711-21. doi:10.1172/JCI9622

55. Woollhead AM, Scott JW, Hardie DG, Baines DL. Phenformin and 5aminoimidazole-4-carboxamide-1-beta-D-ribofuranoside (AICAR) activation of AMP-activated protein kinase inhibits transepithelial $\mathrm{Na}+$ transport across H441 lung cells. J Physiol (2005) 566(Pt 3):781-92. doi:10.1113/ jphysiol.2005.088674

Conflict of Interest Statement: The authors declare that the research was conducted in the absence of any commercial or financial relationships that could be construed as a potential conflict of interest.

Copyright (c) 2017 Gwoździńska, Buchbinder, Mayer, Herold, Morty, Seeger and Vadász. This is an open-access article distributed under the terms of the Creative Commons Attribution License (CC BY). The use, distribution or reproduction in other forums is permitted, provided the original author(s) or licensor are credited and that the original publication in this journal is cited, in accordance with accepted academic practice. No use, distribution or reproduction is permitted which does not comply with these terms. 